\title{
Successful strategies in implementing a multidisciplinary team working in the care of patients with cancer: an overview and synthesis of the available literature [Corrigendum]
}

\author{
Soukup T, Lamb BW, Arora S, Darzi A, Sevdalis N, Green \\ JSA. J Multidisip Healthc. 2018;11:49-61.
}

The title of paper is incorrect and should instead be: Successful strategies in implementing multidisciplinary teamworking in the care of patients with cancer: an overview and synthesis of the available literature.

The Journal of Multidisciplinary Healthcare is an international, peerreviewed open-access journal that aims to represent and publish research in healthcare areas delivered by practitioners of different disciplines. This includes studies and reviews conducted by multidisciplinary teams as well as research which evaluates the results or conduct of such teams or health care processes in general. The journal covers a very wide range of areas and welcomes submissions from practitioners at all levels, from all over the world The manuscript management system is completely online and includes a very quick and fair peer-review system. Visit http://www.dovepress.com/ testimonials.php to read real quotes from published authors. 